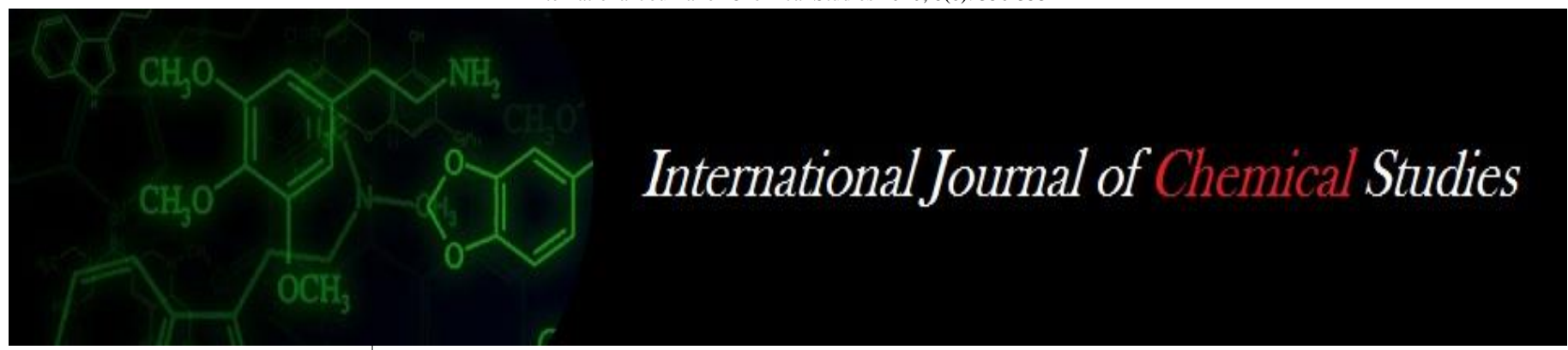

P-ISSN: 2349-8528

E-ISSN: 2321-4902

www.chemijournal.com

IJCS 2020; 8(6): 350-353

(C) 2020 IJCS

Received: 28-09-2020

Accepted: 30-10-2020

Uday Pratap Singh

Department of Agronomy,

C.S.A. University of Agriculture

\& Technology, Kanpur,

Uttar Pradesh, India

Ram Pyare

Department of Agronomy,

C.S.A. University of Agriculture

\& Technology, Kanpur,

Uttar Pradesh, India

RN Maurya

Department of Agronomy,

C.S.A. University of Agriculture

\& Technology, Kanpur,

Uttar Pradesh, India

Mahendru Kumar Gautam

Banaras Hindu University

Varanasi, Uttar Pradesh, India

Corresponding Author:

Uday Pratap Singh

Department of Agronomy,

C.S.A. University of Agriculture

\& Technology, Kanpur,

Uttar Pradesh, India

\section{Effect of growth parameters at different levels of seed rate in wheat under irrigated area}

\author{
Uday Pratap Singh, Ram Pyare, RN Maurya and Mahendru Kumar \\ Gautam
}

DOI: https://doi.org/10.22271/chemi.2020.v8.i6e.10793

\begin{abstract}
Optimum seeding rate is one of the most important production factors for higher grain yield as well as for quality crop. Indiscriminate use of seeding rates not only increases production costs but usually decrease wheat grain yield. Crop sown with quality of seeds, row-spacing of $22.5 \mathrm{~cm}$ and seed rate of $120 \mathrm{~kg}$ ha-1 had better growth and yield. Maximum plant height, number of tillers, length of ear head, grains spiketest weight, biological yield, grain yield and harvest index were found in breeder seed with $22.5 \mathrm{~cm}$ rowspacing at $120 \mathrm{~kg}$ ha- 1 seed rate which was superior over other treatments combinations.
\end{abstract}

Keywords: Harvest index, row-spacing, growth and yield

\section{Introduction}

Wheat (Triticum aestivum L.) is a major cereal crop, which plays an important role in food and nutritional security. It shares upto 40 percent of total food grain production. In India, total area under wheat is 31.0 Mha, with production of $86.53 \mathrm{mt}$ and the productivity of $2.8 \mathrm{t} / \mathrm{ha} 15$. In India Wheat is the world most widely cultivated food grain crop of the family gramineae and second important staple food grain crops next to rice. Bread wheat sowing at the optimum seeding rate and at the appropriate row spacing significantly enhance the number of grains per spike, the spike length, grain weight per spike and 1000- grain weight and then finally produce high grain yield (Iqbal, 2010) ${ }^{[7]}$. Among the factors responsible for low wheat yield, delay in sowing, traditional sowing methods, low seed rate and improper row spacing are very important. Under the present practice of sowing wheat after rice and cotton, wheat sowing often gets delayed, reducing the yield to a considerable extent. Late seeding dates normally result in higher seeding rates because a delay in sowing normally reduces individual plant growth and tiller production. In other words, optimum seeding rate and suitable cultivars play an important role in achieving potential yield of bread wheat (Nizamani et al., 2014) ${ }^{[12]}$. But seeding rate above or below the optimum may reduce the yield significantly (Peter et al., 1988). Row spacing plays a significant role on growth, development, and yield of bread wheat at its optimum level beside it provides scope to the plants for efficient utilization of solar radiation and nutrients (Mali and Choudhary, 2012).

\section{Materials and Methods}

The field trials were conducted during 2016-17 and 2017-18 in two rabi season at Department of Agronomy, CSAUA\&T, Kanpur (U.P) located at 250 26' to 260 58' North latitude. Soil of the experimental site was sandy loam, non-saline, having low in organic matter (0.0.41-0.45\%) and available nitrogen $262.0 \mathrm{~kg} \mathrm{ha}^{-1}$ available phosphorus $13.10 \mathrm{~kg} \mathrm{ha}^{-1}$, available potassium $193.50 \mathrm{~kg} \mathrm{ha}^{-1}$. Three quality seeds (Breeder, Foundation and certified seed) were sown at different row-spacing $(15 \mathrm{~cm}, 22.5 \mathrm{~cm}$ and broadcast) and seed rate (80 and $120 \mathrm{~kg} / \mathrm{ha})$. The experiment was conducted in split plot design with three replications following the procedures of Gomez and Gomez (1984). Land preparation operations were performed for equal distribution of irrigation and fertilizers. Sowing was done with a hand behind the country plough. Wheat (K-307) was sown during second week of November and harvested in the last week of March First irrigation was applied 25 days after sowing. Crop was subsequently irrigated as per need of the crop. Nutrients were applied at $120-60-40$ NPK kg ha-1 in the form of urea, di-ammonium phosphate and mureate of potash respectively. 
All $\mathrm{P}, \mathrm{K}$ and half $\mathrm{N}$ were applied during land preparation at the time of sowing. The second half of $\mathrm{N}$ was split applied at 3rd irrigations. Weed management practices were done manually as well as by using herbicide. At complete loss of green color, the maturity days were counted as difference between sowing to harvest date in each treatment.

\section{Results and Discussion \\ Growth Attributes \\ Number of tillers $/ \mathbf{m}^{2}$}

The number of tillers significantly increased in breeder seed which was higher than foundation and certified seed, respectively in both the years. However, higher number of tillers (404.85 and 417.69) was recorded under breeder seed than foundation seed in both years and lower number of tillers (395.46 and 407.84, respectively) was observed under certified seed. The row-spacing of $22.5 \mathrm{~cm}$ produced significantly more number of tillers (339.08 and 411.64) as compare to $15 \mathrm{~cm}$ row-spacing and minimum number of tillers (372.21 and 384.45) obtained under broadcast in both years of experiment. Number of tillers/m2 maximum observed with $18 \mathrm{~cm}$ and significantly better to rest of the assorted units. Dhiman Mukherjee (2017) ${ }^{[4]}$.

The application of $120 \mathrm{~kg} / \mathrm{ha}$ seed rate recorded significantly higher number of tillers (393.65 and 406.40) than $80 \mathrm{~kg} / \mathrm{ha}$ seed rate (382.44 and 394.51, respectively) during both the years of investigation. The result showed that the number of tillers declined at higher seed rate $(100 \mathrm{~kg} / \mathrm{ha})$ as compared to $80 \mathrm{~kg} / \mathrm{ha}$ and can be attributed to reduced number of tillers and effective tillers Singh et al. $(2013)^{[14,15]}$.

\section{Fresh weight}

The data in table 1 revealed that the significant variation in fresh weight found due to quality seeds at all the growth stages during both years of experimentation. However, highest fresh weight per plant (157.29 and $165.42 \mathrm{~g})$ was recorded under breeder seed than foundation seed at all the growth stages during 2016-17 and 2017-18 and lowest number of fresh weight per plant (141.34 and $148.38 \mathrm{~g}$ ) was observed under certified seed. The row-spacing of $22.5 \mathrm{~cm}$ was found significantly better than all other spacing at all the growth stages of crop during two years of study. However, the maximum fresh weight per plant (154.98 and $162.90 \mathrm{~g}$ ) was obtained under $22.5 \mathrm{~cm}$ row -spacing and higher over broadcast (144.60 and 152.30 g) during 2016-17 and 2017-18. It is clear from the results that applications of different seed rate found significant at all the stages but it is found nonsignificant at 30 DAS during both the years of investigation. However, $120 \mathrm{~kg} / \mathrm{ha}$ level of seed rate at 60 DAS produced maximum fresh weight per plant (152.93 and $160.79 \mathrm{~g})$ as compare to $80 \mathrm{~kg} / \mathrm{ha}$ seed rate $(148.53$ and $156.03 \mathrm{~g}$, respectively). Reported that seed rates of 50, 100,150 and 200 $\mathrm{kg}$ seed $\mathrm{ha}^{-1}$ the effect of seed rates was significant on most of agro-physiological traits. Fresh weight at higher seed rate of $200 \mathrm{~kg} \mathrm{ha}^{-1}$. Hussain et al. (2010) ${ }^{[6]}$.

\section{Dry weight}

The dry weight per plant was significantly influenced by quality seeds at all the stages of crop growth except 30 DAS in two years. However, at harvest stage, highest dry weight per plant (20.66 and $21.70 \mathrm{~g}$ ) was observed under breeder which was higher over certified seed. The lower number of fresh weight per plant (18.12 and $19.03 \mathrm{~g}$ ) was obtained with certified seed during 2016-17 and 2017-18. The results revealed that dry weight per plant was significantly increased at $22.5 \mathrm{~cm}$ row-spacing which was more than $15 \mathrm{~cm}$ rowspacing and broadcast at all the growth stages but at 30 DAS it was found non-significant during 2016-17 and 2017-18. However, the maximum dry weight per plant (20.03 and $20.97 \mathrm{~g}$ ) at harvest stage was recorded with $22.5 \mathrm{~cm}$ rowspacing at all the growth stages of crop and lowest dry weight per plant (18.53 and $19.50 \mathrm{~g}$ ) was recorded under broadcast during both the years of experiment.

The dry weight per plant was significantly increased by different levels of seed rate at all the growth stages but at 30 DAS it was found non-significant in two years of experimentation. The application of $120 \mathrm{~kg} / \mathrm{ha}$ seed rate attained significantly higher dry weight per plant (20.05 and $21.03 \mathrm{~g}$ ). However, minimum dry weight per plant (18.93 and $19.88 \mathrm{~g}$ ) was observed in $80 \mathrm{~kg} / \mathrm{ha}$ seed rate during both the years of experiment

\section{Yield Attributes \\ Number of grains/ear}

It is evident from the data that there was a significant variation found in number of grains/ear due to quality of seeds in two years. However, breeder seed produced maximum number of grains/ear (53.798 and 56.43) and minimum number of grains/ear (48.36 and 50.76) was observed in certified seed during 2016-17 and 2017-18. The data showed that the row-spacing of $22.5 \mathrm{~cm}$ was found significantly better than all other treatments in both years. However, maximum number of grains/ear (52.96 and 55.60) was obtained under $22.5 \mathrm{~cm}$ row-spacing. While, minimum number of grains/ear (49.50 and 51.87) was recorded under broadcast during both the years of study. The effect of row spacing (20, 30 and 40 $\mathrm{cm}$ ) on wheat morphology and grains per spike was studied. The maximum grains per spike were observed in the $40 \mathrm{~cm}$ spacing. Khalil, S. K. et al. (2000) ${ }^{[8]}$. The level of $120 \mathrm{~kg} / \mathrm{ha}$ seed rate significantly produced highest number of grains/ear (52.32 and 54.90) as compare to $80 \mathrm{~kg} /$ ha seed rate $(50.79$ and 53.28) during both the years of investigation. Statistical analysis of the data revealed that the plots treated with $150 \mathrm{~kg}$ $\mathrm{ha}^{-1}$ seed rate had higher number of grains spike- Ijaz Ahamd Khan et al. (2002) ${ }^{[9]}$.

\section{Weight/ear}

The data on weight/ear increased significantly in both years. The breeder seed was found significantly better than all other treatments, hence, maximum weight/ear (2.91 and $13.04 \mathrm{~g})$ was observed under breeder seed during 2016-17 and minimum weight/ear (2.61 and $2.74 \mathrm{~g}$ ) was recorded with certified seed during both the years of investigation. The rowspacing exhibit significantly differences in weight/ear during both the years of experiment. The row- spacing of $22.5 \mathrm{~cm}$ produced maximum weight/ear (2.87 and $3.0 \mathrm{~g})$ which was statistically similar during first year with $15 \mathrm{~cm}$ row-spacing and higher than certified seed. Among different level of seed rate, $120 \mathrm{~kg} / \mathrm{ha}$ produced significantly highest weight/ear ( 2.83 and $2.96 \mathrm{~g}$, respectively) and $80 \mathrm{~kg} / \mathrm{ha}$ seed rate provide lowest weight/ear (2.74 and $2.87 \mathrm{~g}$ ) during 2016-17 and 201718.

\section{Economic yield \\ Harvest index}

It is obvious from the data that harvest index was influenced significantly by the quality of seeds. However, the highest harvest index (38.14 and 37.88\%) was recorded with breeder seed fallowed by Foundation (37.72 and 37.20\%) and 
certified seed (36.90 and $36.11 \%$ ) during both the years of study.

During row-spacing maximum harvest index (37.88 and $37.48 \%$ ) was significantly produced under the $22.5 \mathrm{~cm}$ rowspacing and minimum harvest index (37.18 and $36.52 \%)$ was recorded under the broadcast in both the years. Wheat was sown at row spacing of 20,30 and $40 \mathrm{~cm}$, Row spacing significantly affected harvest index was found in $20 \mathrm{~cm}$ row spacing. Result of this study is agreement with Ahmad, J. et al. $(2005)^{[1]}$. It is clear from the data the highest harvest index (37.73 and $37.31 \%$ ) significantly was observed under the $120.0 \mathrm{~kg} / \mathrm{ha}$ seed rate as compare to $80 \mathrm{~kg} / \mathrm{ha}$ seed rate $(37.48$ and $36.74 \%$ ) during 2016-17 and 2017-18. Significant effects between seeding rates were detected on harvest index. The highest harvest index was recorded for seeding 300 seeds m2 ), while the lowest values were found for seeding 100 seeds $\mathrm{m}-2$. The results of the study reported by Essam A. and Abd El-Lattief (2014) ${ }^{[5]}$.

Table 1: Effect of different treatments on Number of tillers $/ \mathrm{m}^{2}$, Fresh weight $(\mathrm{g})$ and Dry weight $(\mathrm{g})$

\begin{tabular}{|c|c|c|c|c|c|c|}
\hline \multirow{2}{*}{ Treatments } & Number of tillers/m & Fresh weight (g) & \multicolumn{2}{c|}{ Dry weight (g) } \\
\cline { 2 - 7 } & $\mathbf{2 0 1 6 - 1 7}$ & $\mathbf{2 0 1 7 - 1 8}$ & $\mathbf{2 0 1 6 - 1 7}$ & $\mathbf{2 0 1 7 - 1 8}$ & $\mathbf{2 0 1 6 - 1 7}$ & $\mathbf{2 0 1 7 - 1 8}$ \\
\hline \multicolumn{7}{|c|}{ Quality seeds } \\
\hline Breeder & 404.85 & 417.69 & 157.29 & 165.42 & 20.66 & 21.70 \\
\hline Foundation & 395.46 & 407.84 & 153.57 & 161.43 & 19.69 & 20.64 \\
\hline Certified & 363.82 & 375.83 & 141.34 & 148.38 & 18.12 & 19.03 \\
\hline SE(d) \pm & 2.87 & 3.29 & 2.00 & 2.53 & 0.24 & 0.31 \\
\hline CD at 5\% & 7.98 & 9.15 & 5.57 & 7.03 & 0.69 & 0.87 \\
\hline \multicolumn{7}{|c|}{ Spacing } \\
\hline 15.0 & 392.85 & 405.26 & 152.62 & 160.01 & 19.91 & 20.88 \\
\hline 22.50 & 399.08 & 411.64 & 154.98 & 162.90 & 20.03 & 20.97 \\
\hline Broadcast & 372.21 & 384.45 & 144.60 & 152.30 & 18.53 & 19.50 \\
\hline SE(d) \pm & 2.20 & 2.48 & 1.51 & 1.67 & 0.20 & 0.25 \\
\hline CD at 5\% & 4.81 & 5.41 & 3.29 & 3.65 & 0.45 & 0.54 \\
\hline \multicolumn{7}{|c|}{ Seed rate } \\
\hline 80 & 382.44 & 394.51 & 148.53 & 156.03 & 18.93 & 19.88 \\
\hline 120 & 393.65 & 406.40 & 152.93 & 160.79 & 20.05 & 21.03 \\
\hline SE(d) \pm & 2.91 & 3.29 & 2.00 & 2.11 & 0.26 & 0.32 \\
\hline CD at 5\% & 6.11 & 6.92 & 4.22 & 4.44 & 0.55 & 0.68 \\
\hline
\end{tabular}

Table 2: Effect of different treatments on Number of grains/ear, Weight/ear (g) and Harvest index (\%)

\begin{tabular}{|c|c|c|c|c|c|c|}
\hline \multirow{2}{*}{ Treatments } & Number of grains/ear & \multicolumn{2}{c|}{ Weight/ear (g) } & Harvest index (\%) \\
\cline { 2 - 7 } & $\mathbf{2 0 1 6 - 1 7}$ & $\mathbf{2 0 1 7 - 1 8}$ & $\mathbf{2 0 1 6 - 1 7}$ & $\mathbf{2 0 1 7 - 1 8}$ & $\mathbf{2 0 1 6 - 1 7}$ & $\mathbf{2 0 1 7 - 1 8}$ \\
\hline \multicolumn{7}{|c|}{ Quality seeds } \\
\hline Breeder & 53.79 & 56.43 & 2.91 & 3.04 & 38.14 & 37.88 \\
\hline Foundation & 52.52 & 55.09 & 2.83 & 2.97 & 37.72 & 37.20 \\
\hline Certified & 48.36 & 50.76 & 2.61 & 2.74 & 36.90 & 36.11 \\
\hline SE(d) \pm & 0.60 & 0.65 & 0.03 & 0.03 & 0.12 & 0.15 \\
\hline CD at 5\% & 1.68 & 1.80 & 0.08 & 0.09 & 0.33 & 0.41 \\
\hline \multicolumn{7}{|c|}{ Spacing } \\
\hline 15.0 & 52.22 & 54.81 & 2.82 & 2.96 & 37.73 & 37.09 \\
\hline 22.50 & 52.96 & 55.60 & 2.87 & 3.00 & 37.88 & 37.48 \\
\hline Broadcast & 49.50 & 51.87 & 2.67 & 2.80 & 37.18 & 36.52 \\
\hline SE(d) \pm & 0.45 & 0.47 & 0.02 & 0.02 & 0.08 & 0.10 \\
\hline CD at 5\% & 0.98 & 1.03 & 0.05 & 0.06 & 0.18 & 0.23 \\
\hline \multicolumn{7}{|c|}{ Seed rate } \\
\hline 80 & 50.79 & 53.28 & 2.74 & 2.87 & 37.48 & 36.74 \\
\hline 120 & 52.32 & 54.90 & 2.83 & 2.96 & 37.73 & 37.31 \\
\hline SE(d) \pm & 0.59 & 0.67 & 0.03 & 0.03 & 0.11 & 0.12 \\
\hline CD at 5\% & 1.23 & 1.42 & 0.06 & 0.07 & 0.24 & 0.25 \\
\hline
\end{tabular}

\section{Conclusion}

Breeder seed at $22.5 \mathrm{~cm}$ row-spacing along with seed rate of $120 \mathrm{~kg}$ ha-1 increased significantly at all the treatments as compare to foundation seed and $15 \mathrm{~cm}$ spacing with $80 \mathrm{~kg} / \mathrm{ha}$. However, maximum number of tillers, fresh and dry weight, number of grains/ear, weight/ear and harvest index were found under the treatments combination of Breeder seed, 22.5 $\mathrm{cm}$ spacing and $120 \mathrm{~kg} / \mathrm{ha}$ as compare to certified seed, broadcast and level of $80 \mathrm{~kg} / \mathrm{ha}$ seed rate combination.

\section{References}

1. Ahmad J, Chowdhry MA. Effects of different ploidy levels of wheat (Hexaploids and Tetraploids) on seed set, embryo formation and haploid production in wheatx maize crosses. Pak J Biol Sci 2005;8:1758-1761.

2. Beuerlein JE, LaFever HN. Yield of soft red winter wheat as affected by row spacing and seeding rate. Applied agricultural research (USA) 1989.

3. Caglar O, Bulut S, Karaoglu MM, Kotancilar HG, Ozturk A. Quality response of facultative wheat to winter sowing, freezing sowing and spring sowing at different seeding rates. Journal of Animal and Veterinary Advances 2011;10:3368-3374.

4. Dhiman Mukherjee. Evaluation of Performance of New Wheat Cultivar under Different Row Spacing, Int. J Curr Microbiol App Sci 2017;6(6):3186-3191. 
5. Essam Abd El-Lattief A. Determining the optimization seeding rate for improved productivity of wheat under Southern Egypt conditions, International Journal of Agronomy and Agricultural Research (IJAAR) 2014;4(1):47-57.

6. Hussain S, Maqsood MA, Rahmatullah M. Increasing grain zinc and yield of wheat for the developing world: A Review. Emirates Journal of Food and Agriculture 2010, 326-339.

7. Iqbal M, Ashraf M. Changes in hormonal balance: a possible mechanism of pre- sowing chilling- induced salt tolerance in spring wheat. Journal of Agronomy and Crop Science 2010;196(6):440-454.

8. Khalil SK, Khan AZ, Paigham S, Baloch AR, Malik MF. Herbicides and row spacings effect on leaf characteristics and grains per spike of wheat. Sarhad Journal of Agriculture 2000;16(1):13-17.

9. Khan IA, Bakht J, Shah WA, Khan N, Ullah I. Effect of seed rate on the yield and yield components of wheat under irrigated conditions of Peshawar. Asian Journal of Plant Sciences 2002.

10. Kumar R, Nanwal RK, Agarwal SK. NPK content and uptake as affected by planting systems, seed rates and $\mathrm{N}$ levels in wheat (Triticum aestivum L.). Haryana Agric Univ J Res 2006;36(2):93-96.

11. Mali H, Choudhary J. Performance of bread wheat (Triticum aestivum L.) varieties under different row spacing. Journal of Wheat Research 2013, 4(2).

12. Nizamani GS, Tunio S, Buriro UA, Keerio MI. Influence of different seed rates on yield contributing traits in wheat varieties. Journal of Plant Sciences 2014;2(5):232236.

13. Ozturk A, Caglar O, Bulut S. Growth and yield response of facultative wheat to winter sowing, freezing sowing and spring sowing at different seeding rates. Journal of Agronomy and Crop Science 2006;192(1):10-16.

14. Singh Har Vir, Jha Girish, Babu Subhash, Jha AK. Effect of seed rate and sowing depth on growth, yield attributes and yield of irrigated wheat (Triticum aestivum) in Madhya Pradesh, Indian Journal of Agronomy 2013;58(2):259-261.

15. Singh HV, Jha G, Babu S, Jha AK. Effect of seed rate and sowing depth on growth, yield attributes and yield of irrigated wheat (Triticum aestivum) in Madhya Pradesh. Indian Journal of Agronomy 2013;58(2):259-261.

16. Stöppler H, Kölsch E, Vogtmann H. The influence of sowing date, seed rate, and variety on agricultural characteristics of winter wheat in a low external input system. Journal of Agronomy and Crop Science 1990;165(1):28-38.

17. Tripathi SC, Chander S, Meena RP. Effect of early sowing, $\mathrm{N}$ levels and seed rates on yield and yield attributes of different wheat (Triticum aestivum) varieties. Indian Journal of Agronomy 2013;58(1):63-66. 